\title{
Entre a coesão e a coerção: conflitos no exercício da música no Brasil colonial
}

\author{
Diósnio Machado Neto* \\ Universidade de São Paulo
}

\begin{abstract}
Resumo:
A festa no Antigo Regime era um espaço fundamental para a representação do poder. Independente do gênero, civil ou religioso, as celebrações públicas constituíam parte primordial dos índices de sociabilização, tanto entre a Coroa e os súditos como entre as instituições administrativas e as outras coroas. Através de um corpo rígido de cerimônias, o poder estabelecido criava uma litúrgica cívica, idiossincrática, estabelecendo a priori uma relação de dependência entre os súditos e o soberano pela forte marca dos simbolismos cristalizados na representação do poder; em síntese, era a vigência de um paradigma estamental da sociedade. No entanto, a festa também constituía um espaço de negociação, já que a representação de uma sociedade em tese rígida nas relações interclasses nem sempre ocorria dentro da harmonia desejada. Assim, tanto as formas dramáticas como os padrões de administração do espaço lúdico constituíam-se no vórtice de negociações veladas ou explicitas, forjadas não só nos conceitos políticos, mas também nas realidades possíveis de exercício do poder. Esse artigo trabalha justamente com os conflitos que envolviam músicos, músicas e autoridades, religiosas ou civis, na consecução das festas no Brasil colonial. Através do estudo de casos, o texto tenciona demonstrar os usos e costumes do exercício da profissão e as suas relações com os paradigmas das políticas vigentes.
\end{abstract}

Palavras-chave: festas; ideologia; conflitos; música colonial; Brasil

\footnotetext{
* Diósnio Machado Neto é graduado pela Pontificia Universidad Catolica de Chile (1992). Possui mestrado e doutorado em Musicologia pela Universidade de São Paulo (2001; 2008), tendo como orientadores José Eduardo Martins (mestrado); Mário Ficarelli (doutorado); e Régis Duprat e Mário Vieira de Carvalho como co-orientadores. Ingressou no corpo docente do Departamento de Música da ECA/USP em 2002. Atualmente é professor de graduação no Campus de Ribeirão Preto, onde ministra aulas de História da Música, Música Brasileira e Apreciação Musical, e de pós-graduação em São Paulo.
} 
Desde a Antiguidade, a celebração pública era um instrumento primordial para consolidar as zonas de poder e influência. Porém a partir do século IV da era cristã, no vórtice das reformas de Diocleciano (princípio do dominus e do colonus) e Constantino (a unidade do poder temporal com a Igreja), o espetáculo do poder ganhou ainda maior significância, tanto pelos novos projetos políticos como pela possibilidade de mitigar a energia revolucionária tradicional das massas, em Roma. Alicerçando a coesão social sob o manto da autoridade despótica, mediada inexoravelmente pela religião, principalmente a partir do Édito de Milão, a liturgia do poder tratava sempre de sedimentar o projeto de dominação pela aclamação plena do conjunto da sociedade.

Entre outros fatores, essa aclamação era fundamental para a então nova configuração da estabilidade socioeconômica, baseada na servidão do colonus. Esse modelo de produção modificou a estrutura social, tornando o trabalhador livre parte integrante do capital latifundiário. Sem ser autônomo e tampouco escravo, o novo trabalhador se vinculou à reserva senhorial pela estabilidade e segurança: era a formação da vassalagem e de seu princípio de legitimação, baseado no reconhecimento de uma estrutura piramidal de poder. A festa 84 representava um momento singular na construção ou demonstração da "harmonia" entre o poder sacralizado e a rede dos súditos.

Esse processo se intensificou com o tempo na medida em que a Idade Média incorporou e projetou para os séculos seguintes a doutrina monista, na qual a legitimação do domínio político não era dissociada da manifestação da vontade divina (Franco Jr., 1986, p. 97).

Em síntese, como um mote cultural, na civilização ocidental os protocolos cerimoniais se sacralizavam, constituindo no imaginário do conjunto da população o vínculo das cerimônias não só com o poder temporal, mas com a própria possibilidade de redenção da vida através da ligação com o plano divino pela unção do soberano no corpo místico da Criação.

Nesse sentido é que se consubstanciou a vocação para impor liturgias diversas como base da consecução e legitimação da ordem política. O poder era simbolizado e dramatizado, tornando-se um capital imaterial fundamental que se 
inoculava nas doutrinas políticas e jurídicas, princípios administrativos, e até na relação entre os dois gládios do poder: a Igreja e a Coroa. Esse fenômeno acabou se desdobrando na constituição de um sentido estético da vida, ao mesmo tempo em que causou uma instrumentalização política da arte. Ademais, interagiam os postulados da harmonia celestial com a realidade sociopolítica, de modo a formar uma identidade coletiva marcada e estetizada na transubstanciação do corpo político como o ordenador universal.

Assim, nessa tangência da política com a manifestação terrena do divino, a festa incorporava os índices de redenção de uma determinada população, cristalizando crenças e seus respectivos rituais como ferramentas da legitimação do poder temporal. No entanto, esse processo detonava conflitos, já que o diálogo para a constituição do corpo simbólico se constituía no princípio da dominação. Logo, o encontro dos índices dos segmentos e projetos de dominação velava atritos internos e externos entre as várias esferas de constituição do poder. Dessa forma, os conflitos eram inerentes à fórmula de dominação baseada na organicidade entre o laico e o religioso, amalgamado no princípio da predominância através do poder absoluto, do dominus. A busca pelo poder acabava sacralizando manifestações heterodoxas, inclusive da religiosidade popular, assim como "folclorizando" os dogmas religiosos. A festa era o ponto de convergência dessa fusão; como afirma Jaime Almeida: "cada festa é um lugar de memória e utopia, e opera como um foco (disciplinado ou não) de consciência histórica" (apud Lopez, 2004, p. 29).

A música era um elemento fundamental da constituição desse cerimonial e muitas vezes os conflitos de representação estamental ocorriam nas capelas musicais, procissões ou cantorias singelas das ruas. Até mesmo na liturgia e seu patrimônio musical mais íntimo, o cantochão, os aspectos regionais tanto na execução como na constituição de repertório impulsionavam de tempos em tempos "ajustes", que buscavam salvaguardar a religião da cristalização de "distorções" causadas, na ótica dos agentes correcionais, pela má formação dos coros e sacerdotes de uma forma geral, ou porque não, da penetração de 
influências profanas ou heréticas de uma população mal governada, tanto no espiritual como no temporal. ${ }^{1}$

O objetivo desse artigo é mostrar como a música obedecia a esse conceito de trânsito dos valores. Para tanto, o texto foca os embates institucionais forjados nas relações judicativas e/ou administrativas dos instrumentos de controle do exercício do profissional da música e o vínculo - da administração régia e seus instrumentos - com os padrões de comunicação. Estas articulações administrativas traziam velados padrões ideológicos fundamentais para a concretização da própria linguagem musical. O recorte temporal considera um plano de mudanças nas doutrinas políticas, principalmente na passagem da organização do espetáculo público barroco como instrumento da "razão de Estado"2 para o princípio da idéia racional do Estado, articulada nas doutrinas do contratualismo absolutista da segunda metade do século XVIII, que em Portugal floresceu pelo direito natural pufendorfiano (Calafate, 1998, p. 197). ${ }^{3}$

Porém, antes de aprofundar os argumentos da relação da música com esse processo, é fundamental considerar que sendo a festa a manifestação de uma mística redentora coletiva ou um projeto pedagógico para ilustrar em bases

\footnotetext{
${ }^{1}$ Por exemplo, Dom Manuel da Ressurreição, o terceiro na sucessão do Bispado de São Paulo, destituiu o antigo mestre-de-capela e nomeou um jovem músico vindo de Lisboa, André da Silva Gomes; ademais, realizou em 1777 uma avaliação do coro da catedral, excluindo muitos dos antigos cantores que prestavam este serviço (REVISTA DO IHGSP. v. 4, p. 351).

2 Por "Razão de Estado" entende-se a doutrina na qual os meios para a manutenção do poder estabelecido - os homens de Estado - põe a segurança do Estado acima do estado de direito, inclusive usando a violência extrema. Essa doutrina, que se desenvolveu filosoficamente no século XVI, com Maquiavel, dissolveu-se na medida em que a relação entre os Estados considerou como elemento regulador das relações internacionais a ordem jurídica interna de cada nação. Em Portugal, podemos considerar que o reinado de Dom João V manteve-se sob a doutrina da "Razão de Estado", inclusive utilizando a Igreja como elemento de intervenção forte na organização da sociedade.

3 Por direito natural entende-se um direito que submete o conjunto dos homens, independente dos usos e costumes de uma comunidade específica. O direito natural impunha obrigações "naturais" aos homens, entre elas a obediência à vontade de Deus. Sendo a natureza uma criação de Deus e a vida sendo exercida para Deus, as obrigações dos homens desdobravam-se para o ato de obedecer à monarquia que através da vontade de Deus estabeleceu a organização social. É justamente nessa característica que o direito natural português encontra-se com Pufendorf. Para o filósofo, Deus estabeleceu a própria razão humana e por ela os Estados se constituíram.
} 
racionais a opinião pública, os seus protocolos cerimoniais se tornaram no Antigo Regime um exercício político complexo. Grande parte do esforço da política administrava era o estabelecimento dos calendários comemorativos e os trâmites para organizá-los (o repertório de música antiga, celebrado pelos cânones da História da Música, esteve sempre relacionado às festas, fossem na Igreja ou nas Cortes).

Nessa complexa articulação de forças políticas e socioeconômicas imbricadas por ritos calcificados nos usos e costumes comunitários, ocorriam inúmeros conflitos de interesses marcados pelo jogo de poder nas zonas de influências, determinantes para a divisão dos espaços de concretização da vida social. Assim, a festa significava mais do que um momento lúdico ou místico desprovido de interesse material imediato:

Os festejos públicos tinham múltiplas dimensões. Eram imposições da Coroa previstas em lei, mas representavam também a possibilidade de conseguir mercês e aceder a postos do Estado ou consolidar influência já exercida. Ao mesmo tempo, em razão dos recursos que mobilizavam, criavam oportunidades de trabalho para os artífices e de negócios e lucro para negociantes (Lopez, 2004, p. 65).

Justamente por esse aspecto é que a festa no Antigo Regime se consolidava na representação de sua principal base de articulação: a estrutura estamental. Dessa forma, para consolidar e medir a harmonia e os princípios do poder pelos laços da vassalagem, os estamentos eram chamados a participar do corpo político, não com a sua opinião, mas com a representação dramática de si próprios. E nesse movimento de aglutinação do edifício social ocorriam as fragmentações da recepção da tradição, transformando muitas vezes sentidos impostos pelos conflitos entre as ocorrências naturais da existência individual e/ou coletiva de pequena dimensão com os desejos e modos de controle social da política dominante. Por trás da aparente rigidez cerimonial das festas, ocorria uma difusa acomodação de práticas de representação dos valores, onde os embates detonados pela alteridade levavam a estranhamentos onde nunca era possível prever o desenlace: 
[As festas] geravam descontentamentos. Os súditos poderiam resistir, sob as mais variadas escusas, para não cumprir com as obrigações. Isso sugere que a festa era um espaço de conflito social, possuindo linguagem simbólica própria, regras e rituais, que impunham tanto limite como a possibilidade de contestação social (Lopez, p. 65)

Portanto, a festa apresenta uma importante abertura para a observação dos padrões de sociabilidade e das estratégias de consolidação dos princípios ideológicos. Logo, é necessário conceituar a intersecção entre festa e ideologia no decorrer do século XVIII.

$\mathrm{Na}$ festa barroca podemos observar uma articulação para a consolidação da figura mística do Rei - o Deus na Terra - caracterizado pelo fausto das cerimônias que forjavam nos homens uma realidade de fantasia, que redimia a população pela glória do divino. Essa glória era transmutada ao direito do soberano como articulador e redentor da consciência social. Nesse cenário o espaço público era construído pela forte intervenção de controle religioso na constituição da ordem civil.

Já no princípio contratualista que se estabelece em Portugal, em meados do século XVIII, ocorre uma mudança operada na finalidade de cristalizar uma ordem racional e geométrica da sociedade, mediada pela intervenção do corpo civil, através do Estado, na constituição de uma opinião pública esclarecida. A finalidade era a realização de um contrato entre os homens com o objetivo de levar o progresso e conseqüentemente a prosperidade econômica do reino. Nesse ambiente a festa se tornou um instrumento pedagógico para legitimar o poder pela coesão racional dos súditos, através de um consenso do corpo político baseado na diminuição do impacto místico. Nessa doutrina que se estabelece em Portugal, exercida através de um despotismo, o pacto "de consentimento" é mediado e exercido pela ação benfeitora do soberano, que estabelece o próprio corpo legal que rege as relações orgânicas do Estado, inclusive sobre a Igreja.

Partindo desses pressupostos, podemos em parcas palavras afirmar que no decorrer do século XVIII se iniciou uma lenta transformação do espaço social, a partir, também, de uma mudança nos padrões estéticos relacionados com 
alterações nos protocolos cerimoniais. Foi dessa forma que a "razão do Estado" foi cedendo espaço para uma política de cunho secular fundada na disposição da administração pública para a fruição das virtudes da sociedade civil. Um dos paradigmas era que o campo estético, o belo, deveria se "identificar com a estrutura inteligível das coisas, e em última análise, com a verdade" (Calafate, 1993, p. 150). Esse aspecto revitalizou, por exemplo, a discussão sobre a retórica (p. 150) que, indiretamente, incidiu sobre aspectos do discurso musical, combatendo, por exemplo, a estética da retórica figurativa do barroco.

Ao desenvolver o discurso do pedagogismo, a elite intelectual e a larga gama de agentes régios renovaram-se esteticamente, refletindo um aspecto fundamental do despotismo esclarecido: o trato político da arte e do conhecimento. Esse processo foi marcado por um redimensionamento da organização lúdica, tanto no aspecto físico como ideológico. Nessa articulação, a demonstração da autenticidade e a legitimação do poder do Rei vinham através dos espetáculos públicos, que "exigiam" das várias camadas que formavam a sociedade uma demonstração de coesão e submissão a esse poder. Nas celebrações de datas importantes cívicas e religiosas, os desfiles e procissões mantinham a tradição portuguesa de dar espaço para que etnias, grêmios de ofícios e grupos religiosos, como as irmandades, representassem suas identidades através de carros alegóricos, cantos e danças. Representando passivamente a diversidade diante da autoridade, a festa legitimava a unidade social sob a égide do Estado. Nesse modelo todos encontravam espaços para expressar parte de suas respectivas culturas, principalmente aquelas que não se opunham aos princípios do catolicismo, na forma de danças, músicas e vestimentas, tornando a identidade passiva e submissa diante do agente civilizador.

No entanto, mesmo tendo espaço para a representação cultural étnica, os protocolos cerimoniais se encontravam sempre no limite do repugnante para a consciência do poder estabelecido. Formada na intersecção de inúmeras raças, sem a mediação onipresente das autoridades régias, como ocorria na Metrópole, a festa no Brasil colonial tornava as matrizes ideológicas amorfas, já que intensificava inerentemente os embates de alteridade na representação do corpo 
social e sua relação com as cerimônias do poder. No Brasil, as formas dramáticas e até a própria liturgia cotidiana não encontravam alicerces para fruir uma consciência de um mundo regido por protocolos rígidos, como seria de praxe no Antigo Regime importado da Europa. O edifício colonial brasileiro refletia sua abertura sincrética, agravada no despreparo dos eclesiásticos seculares; na proliferação de frades apóstatas nas minas; e na autodeterminação religiosa dos organismos internos da Igreja, caracterizada pela forte intervenção das Irmandades na configuração do espaço público da religião e autodeterminação dos bispados e vicariatos.

A conjunção desses e de outros fatores, como a dimensão territorial, se refletiu na forja de uma religiosidade de sincretismo convexo, contrária à natureza ortodoxa do catolicismo europeu (Mott, 1997, p. 155-156). Entre outros aspectos, a dispersão inerente da colônia criava a certeza nos homens de letras e poder da Coroa de que o entendimento da marca do Rei - a consciência vassalar - era contingente e perigosamente tênue. Em inúmeras ocasiões, em diversas épocas, afirmavam governadores, letrados e autoridades eclesiásticas que a gente do Brasil era formada numa impossibilidade humana; ironicamente, o que acabou agravando o fenômeno, a própria matriz lusitana era propensa à acumulação de valores de inúmeras raças na manifestação de sua religiosidade.

E nesse sentido, a festa ganhava maior importância na inoculação dos padrões de sociabilidade desejados pelo colonizador. Como afirma Mary Del Priore, "a festa devia simbolizar o poder do monarca ou do panteão católico" (1994, p. 16). O sistema que regia essa fusão era o padroado, instrumento de unificação dos poderes espirituais e temporais sob a égide de um plenipotenciário - monarca ou nobre -, consagrado pela Igreja. Assim unido sob a Coroa, a administração da Igreja e de suas celebrações tornou-se nos domínios lusitanos um "sistema único de poder e legitimação" (Abreu, 1999, p. 34), que variava de acordo com os paradigmas estabelecidos pelos diferentes monarcas. Porém algo era imutável: a celebração pública constituía o principal elemento de intervenção social, não só pela concretização da vida mística como, também, pela observação do grau de submissão vassalar. 
Portanto, mesmo através de um sistema intrincado e nem sempre claro de atribuições, o Estado assumia a responsabilidade pela organização ou pela observação dos protocolos litúrgicos e etiquetas das celebrações públicas. A articulação dessa imensa máquina envolvia o corpo eclesiástico desde a sua menor célula, o capelão e o padre paroquial, até a estrutura de correção doutrinária mais sofisticada dos tribunais eclesiásticos e o corpo de visitadores que atuava na correção das posturas das cerimônias realizadas nas igrejas, e mais especificamente nas irmandades. Envolvia também a Câmara do Senado e toda a rede de agentes régios, desde o meirinho até os governadores das capitanias e vice-reis.

O sistema de estabelecimento das festas era igualmente complexo, como demonstra Emílio Lopez (2004). A preocupação primordial dos calendários festivos era recordar a trajetória que legitimava o poder, assim como alocar a Coroa no corpo místico do catolicismo. Assim existiam grupos diferentes de festas. As principais eram as Festas Reais, que celebravam datas que enalteciam a realeza e seu vínculo com a constituição do Estado, como o nascimento dos membros da casa real e seus respectivos dias "do Santo". Dentro desse conjunto, ocorriam comemorações em datas eventuais, mas que eram fundamentais para assentar nos súditos a ordem monárquica. Assim, casamentos, coroações, nascimentos e exéquias mobilizavam toda a população na realização das cerimônias públicas. Alinham ainda nas Festas Reais as celebrações da aliança entre a Igreja e o Estado. Nessa categoria estava o dia do padroeiro do reino e/ou do monarca (aqui também podem ser consideradas as festas dos padroeiros dos plenipotenciários, como a dos governadores e vice-reis), a do Divino Espírito Santo; a Páscoa e o Natal (Lopez, p. 32); nos domínios portugueses, a mais simbólica era a do Corpus Christi, que simbolizava a unção do rei no corpo místico da Igreja; porém a mais popular era a festa do Divino Espírito Santo (Abreu, 1999). Todas as Festas Reais contavam com o patrocínio dos Senados da Câmara.

Outro tipo de festa da Coroa, igualmente oficial, mas de menor importância na simbologia do poder, era as festas que celebravam as visitações religiosas ou de autoridades governamentais. Estas eram celebradas com jogos, 
banquetes com serenatas e funções lítero-musicais, inclusive com óperas e comédias. Considera-se nesse grupo as celebrações por vitórias militares: acordos pelo fim de armistícios, ou pela superação de motins ou sedições, geralmente celebradas com um Te Deum em praça pública.

Por fim, as festas de âmbito estritamente religiosas. Lopez indica que essas eram móveis no calendário e poderiam ter "dispensa" de feriado, o que significava que nos dias santos "dispensados", os súditos assistiam à missa nas primeiras horas do dia e, então, iniciavam a jornada de trabalho (p.108).

Nesse grupo, se incluem as festas de âmbito mais restrito, como as promovidas pelas incontáveis irmandades. Sua característica era a circunscrição particular, sem nenhuma possibilidade de suspensão das atividades laborais cotidianas. No entanto, as celebrações das irmandades eram tão ou mais importantes para a formação do espaço público. Em algumas regiões, como Salvador, relatos indicam que não havia dia sem uma celebração dessas associações, desfilando pelas ruas sempre com cantorias acompanhadas de bandas ou "a capela". Ademais, elas traziam a marca dos vários segmentos da sociedade, inclusive dos negros cativos, que se organizavam sob o manto das irmandades católicas; e, dessa forma, algo fluía de seus valores recônditos, ao mesmo tempo em que ingressavam no corpo político do Reino (Reis, 1989, p. 28).

No entanto, como um espaço privilegiado de interlocução dos súditos com a Coroa, as festas potencializavam momentos de manifestação política vertida em posturas que visavam coordenar ajustes na relação vassalar.

Para ter uma visão do problema, tomemos como exemplo a vila de Santos, da Capitania de São Paulo. Apesar de ser uma região litorânea, Santos tinha uma condição socioeconômica mediana. Não poderia ser comparada às principais metrópoles brasileiras, como Salvador, Rio de Janeiro, Recife; ou algumas das vilas mineiras, como Mariana ou Vila Velha (lugar do mais célebre documento, atestando as relações de conflitos e acordos potencializados nas festas: As Cartas chilenas, de Tomás Antônio Gonzaga). Porém, tampouco poderia ser comparada à maioria dos núcleos populacionais do Brasil, onde a situação de privação de infra-estrutura básica, inclusive religiosa, era intransponível. Por essa 
característica podemos observar em Santos o desdobramento da câmara e do povo para cumprirem com suas obrigações vassalares. Isso porque ao não ter as possibilidades das grandes metrópoles, mas ao mesmo tempo não ser miserável como grande parte dos núcleos populacionais do Brasil, os conflitos em Santos se revelavam menos impregnados das lutas políticas das elites coloniais e, ao mesmo tempo, sem a súplica envergonhada daqueles que nunca podiam realizar o calendário festivo.

Iniciemos com a observação dos relatos das festas, que eram fundamentais para apresentar à Coroa os padrões da ordem social e sossego do Reino. Em 1803, a Câmara de Santos relatou, em ata, o cumprimento de suas obrigações cívicas como súditos fiéis:

Sempre foi costume mandar ao Doutor Juiz de Fora presidente mais oficiais do Senado escrever cartas de convite aos comandantes da praça, vigário, prelados dos Conventos e Ordens Terceiras, convidando-os da parte do Senado, por uma carta feita e assinada pelo Escrivão do mesmo Senado para assistirem a festividade de Corpo de Deus que se costuma se celebrar na Igreja Matriz desta vila de onde sai procissão depois da missa cantada cuja praxe sempre se praticou nesta vila de tempo e sobrevivera até hoje (DAESP, Ofícios da Câmara de Santos 1721 - 1822, ord. 236).

Apesar dessa busca por racionalizar a administração pública, não eram poucos os casos em que os vereadores dissimulavam suas ações e compromissos, quando não os ignoravam. A justificativa sempre era a mesma: as parcas condições do erário. Assim, desde remotas épocas, as Festas Reais eram um subterfúgio para discutir-se a relação fiscal entre a Coroa e a Colônia. Com o pretexto de não cumprirem com as tradições cívico-devocionais, as comunidades coloniais, por seus vereadores, reclamavam dos novos impostos, da espoliação de determinado funcionário régio ou religioso, da carestia etc. Como a concretização dessas festas era fundamental, até mesmo respondendo a uma mística religiosa, por que não dizer à superstição, a impossibilidade de realizá-la era tida, por todos, como uma grave falta, uma verdadeira "vexação para o povo", e potencialmente perigosa para a relação entre os homens e Deus. Logo, com malícia ou zelo, os súditos manuseavam-na, para conseguir benefícios régios que 
aliviassem os mandatícios fiscais do governo monárquico. Em síntese, era a ocasião propícia para se questionar assuntos que normalmente eram regidos de forma unilateral, pela Coroa, estabelecendo negociações que ajustavam o contrato colonial.

Nos remotos anos de 1675, a Câmara de Santos dava uma prova inequívoca da importância das Festas Reais. Em carta dirigida ao Rei, os camaristas relataram as dificuldades para realizarem as ditas festas, por ser a vila pobre e desprovida de rendimentos; mas que mesmo assim a organizaram. No entanto, segundo os republicanos santistas, o ouvidor Pedro de Castel Branco não reconheceu tal fato. Como que temendo uma represália, os camaristas recorrem ao próprio rei para demonstrar o esforço do povo para cumprir as suas obrigações religiosas:

Nesta vila veio o ouvidor geral o Doutor Pedro Vinhão de Castel Branco e não nos quis levar em conta os gastos que com as festas de $V A$ se fizeram, sendo que do principio que desta vila foi feita sempre se observou o fazerem-se, como em todas as demais câmaras desta capitania e [do] Rio de Janeiro e [de] todo o Brasil. E os ouvidores gerais que até o presente tem vindo a esta capitania não reparam que a deixaram no por ordem, senão fariam. E agora nos mandam que recorramos a $V$ A para se nos levarmos em conta. Sendo que até o presente demos por satisfeitos todos os anos depois que foi posto o donativo de $\mathrm{V}$ A sem faltar pagamento nenhum com ver uma vila pobre e a câmara não ter coisa alguma saindo tudo deste povo. Assim que pedimos que $V$ A nos alivie, pois são atos ajustados os gastos das ditas quatro festas, que são trinta e cinco mil reis, por ser em serviço de Deus e de V A que vem em ser em cera para expor o Senhor, Música, e sermões e os vigários [que] não queriam fazer nada sem paga, e estar em costume. E confiando em vossa alteza visto serem os gastos feitos ato lícitos, nos consideramos já aliviados do que a Vossa Alteza pedimos. E daqui por diante faremos o que o dito ouvidor geral nos deixa em capítulos novamente que não façamos gasto algum com as ditas festas, em que V A não ordene o contrario, a quem Deus aumente por largos e felizes anos (AHU, Documentos referentes à Capitania de São Paulo, doc. 26).

Como vimos na referência acima, o não cumprimento das festas deveria trazer mais do que pequenas censuras aos camaristas. Dessa forma, se os cofres das câmaras não cobrissem as despesas, elas seriam rateadas entre os vereadores. Logo, a negociação era um caminho menos oneroso, e a suspensão 
das festas era a ferramenta para abrir-se o diálogo com os órgãos fiscalizadores da colônia, ou mesmo com o próprio Rei.

Essas negociações eram longas e requeriam diversos trâmites: relação de despesas e rendimentos dos suplicantes; parecer do procurador da Fazenda Real, assim como do próprio Conselho Ultramarino. A Coroa não se dispunha facilmente a abrir mão de seus rendimentos; no entanto, preocupava-se com o não cumprimento das tradições lúdicas. Assim, uma alternativa para viabilizar as festas, sem concorrer para a "contribuição" particular dos vereadores e o subsídio do erário régio, era minimizar os custos. Os mais diversos subterfúgios eram utilizados para o êxito dessa tarefa, porém o mais eficaz era buscar pareceres jurídicos que sustentavam jurisprudências para contar com o espetáculo litúrgico sem despender nada.

O problema intensificava-se na medida em que as câmaras deveriam dar provas de sua "obediência" aos protocolos. Era necessário demonstrar que a organização das Festas Reais obedecia a diretrizes básicas; e uma delas era referente à contratação da música. Em um evento que celebrava o nascimento de um membro da família real, em 1817, a Câmara de Santos organizou três dias de festas na Matriz para "homenagear com todas as formalidades devidas segundo os antigos usos desta monarquia" (DAESP, Ofícios da Câmara de Santos 1721 1822, ord. 236, doc. 10-7-92). Entre as várias mobilizações previstas, a música, segundo os relatos dos próprios camaristas, era a melhor que poderia existir na vila:

No dito dia seis pelas cinco horas da tarde fomos a Igreja Matriz onde depois de exposto o Santíssimo Sacramento se cantou um solene Te Deum com toda a música que havia nessa vila, o que assistiu o clero e comunidades, religiosos, todas as autoridades, republicanos e povo, estando desde o principio formada no largo da Matriz toda a tropa que se pode ajuntar comandada pelo brigadeiro Cândido Xavier de Almeida e Souza, para no fim dar os Salvas de Alegria, como fez, e sendo correspondido pelo forte de Nossa Senhora do Monteserrate [sic] [...] // S ${ }^{\text {tos }}$. em Câmara de 7 de Junho de 1817 (DAESP, ord. 236, doc. 10-7-92).

Outra característica eram as formas de contratação para a realização das celebrações. Porém, primeiramente devemos observar que o sistema de 
organização musical vinculava-se primordialmente ao redor do mestre-de-capela. E é justamente nesse ponto que o processo encontrava-se com um campo bastante heterogêneo de forças que fundamentavam inúmeros impasses entre o poder secular e o espiritual.

Por um instrumento jurídico, a nomeação do mestre-de-capela estava vinculada a provisões régias, passadas por plenipotenciários com aquiescência ou indicação das autoridades eclesiásticas, desde os primeiros atos administrativos portugueses na colônia (Machado Neto, 2008, p. 63). No entanto, o ato transformou-se no decorrer dos tempos e entrou no século XVIII alterado na sua forma prática. Usando a provisão como um instrumento que se atrelava à concepção de controle da sociedade, assim fundamentando o combate da conspurcação pela moral religiosa, a autoridade eclesiástica tomou para si o direito de nomeação e impôs à comunidade o monopólio das atividades musicais nas mãos do provido, durante principalmente a primeira metade do setecentos. Esse era o modelo do "estanco", exaustivamente analisado em textos de Régis Duprat. ${ }^{4}$

O estanco suscitou não só inúmeros conflitos, mas também uma indeterminação sobre os direitos e deveres do músico e a quem caberia o pagamento de seu trabalho, principalmente na relação com as festas promovidas pelas autoridades régias. Em tese, somente os mestres-de-capela das catedrais estariam vinculados ao erário. No entanto, com o sistema de provisão eclesiástica, os mestres-de-capela de matrizes ou paróquias viviam num nebuloso espaço administrativo, onde muitos confundiam a regência do padroado com a obrigação do erário de suprir todas as coisas de qualquer igreja. No entanto, regia as normas do padroado que a Fazenda Real só tinha obrigação com os mestresde-capela das Sés.

4 Régis Duprat revelou os alcances dessa prática, assim como suas implicações na organização do exercício da música. Em síntese, o provido, mediante o pagamento de uma caução, obtinha o direito de exploração das atividades musicais, na freguesia ou bispado. (O estanco da música no Brasil Colonial. Yearbook. Tulane University, v. IV, p. 98-109, 1968; O Estanco da Música no Brasil Colonial. Art. Salvador, v. 8, p. 3-19, 1983; e O estanco da música no Brasil colonial (1999). 
Em 1728, uma disputa entre o Vigário da Vara da matriz de São Paulo e os vereadores revela o desconhecimento dos próprios agentes régios. Em carta de 1728, diz o governador de São Paulo, Antônio da Silva Caldeira Pimentel:

Na provisão inclusa declara S Maj. que se não deve pagar ao Vigário, por que tem ordenado, e da mesma forma ao Mestre da Música, por também o ter, mas nesta parte há equivocação, ou engano, porque o mestre da música não tem ordenado algum da fazenda de sua Majestade, como da folha da receita, e despesa que todos os anos remete o provedor da fazenda, se justifica e sendo certo que não tem ordenado, é justo que lhe pague a Câmara o seu trabalho, pois não [tem] obrigação para que se haja de cantar de graça, e se lhe devem lhe satisfazer as festas pelo mesmo preço que nas demais igrejas se costuma se pagar nas festas solenes. (AHU, doc. 1138).

A observação do estanco não era obrigatória, porém fazia parte de um acordo consuetudinário; quando este não era observado, causava grande transtorno. Em 1745, pouco antes da criação do bispado de São Paulo, o músico Antônio Antunes arrematou o serviço da procissão do Corpo de Deus que se realizaria na cidade, o que provocou protestos veementes do mestre-de-capela provido da Matriz de São Paulo, o padre Mathias Álvares Torres. Este alegava que, por direito de provisão, dita festa Ihe pertencia e, portanto, a procissão só ocorreria com sua música; e assim foi. (Camargo, 1953, p. 16).

Anos antes, na mesma cidade de São Paulo, a ausência na matriz de um mestre-de-capela com provisão obrigou o Vigário da Vara, Antônio Álvares da Rocha, a contratar a música de um grupo estranho ao templo. No entanto, uma discussão sobre o valor do serviço criou um sério impasse entre as partes, que terminou nos tribunais eclesiásticos. O fato ocorreu na Semana Santa e envolveu o mestre-de-capela Ângelo de Siqueira (1707 - 1771), membro da então mais tradicional família de músicos da capitania. A máxima autoridade religiosa, residente em São Paulo, acusou o músico de:

[...] não ir cantar na Semana Santa na Igreja Matriz desta cidade pelo estipêndio concordado que sempre assinou com o antecessor dele reverendo autuante (sic), o mandou notificar no primeiro dia do corrente mês de abril para que assinasse o dito estilo com declaração que a sua revelia se chamarão a outros, e no dia seguinte Domingo de Ramos acedera 
somente o autuado com uma capela pelo que se dá (sic) por o reverendo autuante a celebrar os ofícios sem musica, o que vendo o reverendo Padre Antonio Nunes de Siqueira e Antonio Peres Santiago entraram a cantar, e assim se fez a função. (ACMSP, PGA, Crime, São Paulo, Alves Rocha Ângelo de Siqueira).

Conflitos sobre remuneração não eram raros. Inúmeras fontes, de diversos períodos da era colonial, relatam um número considerável de queixas dos profissionais da música contra a opressão principalmente do corpo eclesiástico. Na época em que o estanco foi exercido com mais rigor, na primeira metade do século XVIII, os libelos se sucediam ininterruptamente (cf. Duprat, 1999). Por esse ponto de vista, o que aparentemente seria uma singularidade do caso supracitado, era freqüente na relação entre músicos e a Igreja. Ocorreram casos em que o bispo mandou prender um mestre-de-capela que insistia em cantar sem provisão (p. 64); outros, em que as irmandades se organizavam para reagir às visitas de vedores episcopais, que vinham fiscalizar as práticas cerimoniais, inclusive os papéis de música (Eugênio, 2002); e outros em que os conflitos eram de menor dimensão, porém sempre caracterizados pela revolta do monopólio da Igreja na administração da música.

No entanto, o caso revela uma sutileza: a negociação entre a Igreja e os músicos ficou impregnada de um sentido na qual a provisão tornou-se a única mediadora possível para o exercício da música. Ângelo de Siqueira na ocasião não era mestre-de-capela da matriz paulistana e assim não estava na jurisdição do Vigário da Vara. Isso obrigou o eclesiástico a estabelecer uma relação de mercado com o músico, o que parece ter-Ihe desagradado a tal ponto de levar o caso aos tribunais eclesiásticos.

Ademais, o que contribui para o agravo do caso supracitado é um aspecto fundamental da relação administrativa da música nesse espaço regido pela "razão do Estado": a legitimidade do músico diante da autoridade constituída. O mestre-de-capela paulistano contava com a aquiescência da comunidade, até mesmo pela tradição da sua família no trato da música religiosa. Em nenhum momento o padre Alvarez da Rocha substituiu o mestre-de-capela, reconhecendo implicitamente que o músico era a melhor alternativa para a 
principal solenidade do ano, a Semana Santa. E, portanto, a sua rebeldia ao não aceitar o acordo representava uma ofensa passível de acusação... Coincidentemente, sob Ângelo de Siqueira caiu uma suspeita de ser cristão-novo. A acusação desconsiderou até o fato de na sua família inúmeras pessoas terem o estado eclesiástico, inclusive um seu irmão, o mestre-de-capela licenciado Manoel Lopes de Siqueira (1692 - 1725). Ademais, os Siqueira eram figuras principais no exercício da música em São Paulo desde 1681! Enfim, revelava-se a doutrina das autoridades locais, forjada nas matrizes da "Razão de Estado" e estabelecido no braço de correção social para o projeto civilizador. E nesse jogo, o que valia era a preservação da autoridade, mesmo sendo por instrumentos escusos e, invariavelmente, difamatório e violento.

Porém, a inconformidade do vigário e a própria manutenção do músico, mesmo diante da suposta sedição, revela outro aspecto primordial da época: a luta contra a penetração de discursos estranhos à ortodoxia católica, ou o que se imagina que seria a ortodoxia: Ângelo trazia consigo a tradição. Em síntese, na violência do caso residia também a visão de manutenção da forma dos cultos da religião dominante, que reagia institucionalmente às práticas religiosas construídas no caldeirão da diversidade étnica, da movimentação estamental, e da própria falta de estrutura da Igreja e do Estado no Brasil.

E esse processo tem certidão de nascimento: a descoberta das jazidas de ouro. A partir dessa época, a mentalidade do perigo interno, forjado na impossibilidade da civilização brasílica, se intensificou sobremaneira. É bem verdade que, desde a Restauração, a colônia americana era vista como terra de gente no estado de natureza bárbara. Porém, ao aumentar a dependência econômica, o Reino passou a olhar a colônia com maior interesse. Houve até mesmo os que imaginaram a revitalização do Império a partir do Brasil, entre outros, Antonil, Gabriel Soares e Nuno Marques Pereira (Souza, 2006, p. 100). E na fundamentação da idéia do centro brasílico, a correção moral se tornou então o princípio ativo da estrutura que "tratava de instrumentalizar as colônias para reforçar a posição européia de Portugal" (p. 107). Assim, o que era uma visão desarticulada, no século XVII, inoculou um discurso canônico e independente da 
posição social, no reinado de Dom João V. Não houve letrado, eclesiástico, burguês ou nobre em serviço, no além-mar, que não buscasse as origens do desregramento social no comprometimento da civilização pela barbárie de uma gente marcada pela licenciosidade.

Entre os elementos destacados da imiscuidade social, que conspurcava a moral dos reinóis, estavam danças e canções profanas. Nos índices de valores refutáveis para a civilização moralizada, as coreografias "descompostas e provocativas 'a qual parece a invenção do demônio'” (apud Budasz, 2004, p. 25), como o lundu, negligenciavam as virtudes necessárias à disciplina social. Apoiado nesse conceito, o puritanismo das autoridades eclesiásticas e civis brasileiras insistiam até mesmo na censura ou proibição das "européias" sarabanda e chacona (Budasz, p. 23). Alguns moralistas, como Nuno Marques Pereira, não cansavam de sublinhar que as "profanidades indecentes" eram o mote das canções que faziam o gosto da população de uma forma geral. Expunham seus motivos pela percepção de que "o profano das modas e malsoante conceito" era de uso coletivo "que não havia negra, nem mulata, nem mulher dama, que não o cantasse." (Marques Pereira apud Tinhorão, 2000, p. 22). Na tese puritana de Marques Pereira, "músicas profanas e palavras desonestas [eram] a mesma coisa, porque o mesmo é cantar que contar: e a diferença que há entre uma coisa e outra, é ser uma harmoniosamente dita e a outra proferida praticando." (p. 22).

No entanto, a política portuguesa nem sempre definia um padrão de correção em relação aos problemas oriundos de uma sociedade escravocrata e desprovida de uma elite de sangue. Inúmeras vezes os batuques e danças dos negros recebiam tratamento condescendente; outros eram reprimidos com energia. Em 1738, um grande escândalo se formou quando, na procissão do Divino Espírito Santo, um carro alegórico apresentou-se com padres seculares e com uma negra vestida de homem cantando uma arromba, acompanhada de viola (Budasz, p. 27). O alvoroço se desdobrou em uma devassa que não se deteve nem mesmo diante da moção ingênua, típica da devoção popular.

Já em 1794, na vila de São Sebastião, a câmara comemorou o nascimento da Princesa da Beira, Dona Maria Thereza, com a participação ativa 
dos "homens pardos". Na demonstração de unidade ao redor da Coroa, as etnias africanas, e seus membros escravizados ou libertos, externaram seu júbilo com expressões europeizadas, como as contradanças, assim como danças da tradição ancestral, como os bailes do congo. Assim, podemos ver na relação de festa da câmara do senado, ocorrida nos últimos dias de 1793:

Aos 28, contradança de homens pardos em [praça] da Câmara e continuadas pelas ruas, e luminárias à noite na cadeia e casas da comarca // Aos 29 Baile de Congos feitos pelos homens pardos em [praça] da Câmara, oficiais dos ofícios mecânicos e auxiliares da Câmara, e repetidas vezes pelas ruas [...] // Aos 30 à noite entremeses feitos pelos homens pardos repetidas vezes pelas ruas [...] // Aos 31 outro Baile de Congos [...] Ao $1^{\circ}$ de Janeiro houveram cavalhadas [...] e correrão argolinha, e várias orações tudo a custa da câmara [...] // Aos 2 uma dança feita pelos auxiliares, em presença da Câmara e pelas ruas [...] Aos 3 houve entremeses feitos pelos homens brancos [...] Aos 4 houve vários entremeses à noite feito pelos auxiliares repetidos pelas ruas [...] // Aos 5 houve cavalhada...e à noite se representou uma comédia pública à custa da Câmara [...] Aos 6 houve à noite um castelo de fogo com uma contradança dos homens pardos e um letreiro que dizia viva a Princesa da Beira [...] (DAESP, Ofícios da Câmara de São Sebastião 1721 - 1816).

Outro acontecimento exemplar sobre a relação ambígua com as formas dramáticas da população ocorreu em Pernambuco, em 1779. Segundo o governador da Capitania, José César de Menezes, dois frades barbadinhos italianos invadiram uma casa e quebraram os instrumentos dos negros. O governador relata que repreendeu os religiosos e reparou os citados artefatos (apud Silva, 2005, p. 277). Como bem explica Luiz Geraldo Silva (2005), o caso mostra as divisões sobre os conceitos de religião até entre as principais autoridades. Para o governador, as danças dos negros inseriam-se dentro dos limites do catolicismo consuetudinário; para os religiosos capuchinos italianos, o caso merecia, como mereceu, uma denúncia ao Santo Ofício, que inclui nos autos uma acusação ao governador como "protetor das danças gentílicas" (p. 278).

Pese a diversidade da postura local, a Coroa tratava de manter a unidade do Império atlântico, ungindo a ordem pela imagem do Rei, místico apoiado pela Igreja ou racional e apoiado na elite intelectual de cultura secular. Dessa forma, o diálogo com a população entrava num espaço ora corrigido pela postura 
individual, que poderia ter laços de coesão ou coerção sumária, como era freqüente nos ambientes barrocos e sua razão de Estado; ora exercido pela geometria da razão, consubstanciada em posturas, constituições, compromissos, enfim por um corpo normativo correspondente a todas as esferas do edifício social.

Dessa forma, nesse problema devemos observar a diferença dos tempos. Na primeira metade do século XVIII, o controle da Igreja tornou-se o mote fundamental da política de Estado, via Padroado. Nesse princípio, o poder sobre o espetáculo público, no qual a Igreja era orgânica, era determinante para a segurança monárquica, principalmente na colônia. Assim, mesmo publicamente combatido, o estanco que a Igreja exercia sobre os músicos atendia uma necessidade básica, que era intervir nas formas de culto da população, considerada inerentemente conspurcada.

A canção profana foi um dos principais alvos das ações do estanco. Em todas as determinações das provisões eclesiásticas estava a determinação ao mestre-de-capela de coibir os cantos "indecentes". Assim, vemos na provisão de Ângelo de Siqueira, de 1733, emitida pelo Bispado do Rio de Janeiro:

[...] Sendo obrigado a zelar que nas Igrejas não haja músicas e [cantos] profanos [sic] e indecentes assim que sejam todos graves e dignos do nome de [...] Deus mandamos ao dito mestre-de-capela de que todos os papéis que fizer cantar sejam com este requisito e não consintam cantos ou vilancicos profanos e indecentes. Mandamos ao Reverendo Pároco, sob pena de excomunhão, que não deixem cantar música alguma nas suas igrejas e capelas das suas freguesias pela qual não conste que vão examinados e aprovados os papéis que hão de cantar em cada ocasião pelo dito mestre-de-capela [...] (AHU, doc. 1138).

O mesmo teor, praticamente com as mesmas palavras, que denota um padrão de documento, encontra-se na provisão para mestre-de-capela da Sé do Rio de Janeiro para João Lopes Ferreira, de 1770 (apud Mattos, 1997, p. 217). Anos antes, em 1753, o Bispo de Mariana, Dom Frei Manuel da Cruz, recorreu à mesma determinação da censura dos papéis de música executados nas Irmandades. Dizia que seria uma obrigação do mestre-de-capela observar os papéis de música para 
[...] evitar as incidências e profanidades das músicas nas capelas, e todos deveriam ouvi-las assentados com honesta decência [e que] não consintam nas festividades músicas que não sejam páginas fixadas pelo Breviário e o Missal Romano, e para isso examinem os papéis dos músicos, sob pena de excomunhão maior [...] (Frei Manuel da Cruz, 1753, apud Eugênio, 2002).

Coligada a essa preocupação estava um problema de fundo na organização civil imposta pela política portuguesa desde o século XVII: as irmandades, um dos principais agentes da integração entre o espaço civil e o religioso. Essas associações foram inerentes às formas de expressão religiosa do catolicismo, a partir do século XVI. No entanto, no vórtice de uma administração pública forjada para um ambiente de obediência e disciplina social mediada pela religiosidade, mas exercida no desequilíbrio estamental que expunha as contradições do próprio modelo do Antigo Regime, as irmandades ganharam uma considerável importância como elemento mitigador das diferenças étnicas e sócias da colônia. Até mesmo as etnias escravizadas foram "estimuladas" a organizarem-se em irmandades e assim, ingressar no corpo político da Coroa, como afirma Luiz Geraldo Silva (2005). Para Charles Boxer (apud Souza, 2006, p. 42) a divisão de poder nos núcleos populacionais da colônia estava vinculada ao Senado da Câmara e às associações religiosas leigas, principalmente as Misericórdias.

No entanto, as irmandades traziam uma ambigüidade inerente que suscitava inúmeros conflitos com a autoridade eclesiástica. E nessa luta contra os desvios da prática religiosa, as irmandades eram freqüentemente "ajustadas" por visitadores que questionavam, principalmente em meados do século XVIII, as formas de manutenção do compromisso regimentar. A ostentação das festas, que por vezes reuniam um corpo musical insólito, nem sempre era vista como atos de devoção aprovados pela Igreja:

Estando em visita nesta freguesia de Santo Antônio do Itatiaia, comarca de Ouro Preto, os irmãos da Irmandade de Nossa Senhora do Rosário e São Benedito nos apresentaram este livro de contas, e vendo o que nele se acham, havemos por incapaz para se fazerem as festas com tanta solenidade 
quando se vê pelas despesas que são feitas, consumindo nelas o rendimento da Irmandade, ficando os irmãos sem sufrágios anuais, não sendo ereto para o proveito das almas dos que falecem, e sim para a ostentação humana, pelo qual só é que fazem tantos festejos (Frei João da Cruz, 1742, apud Eugênio, 2002, p. 34).

Argumentavam os visitadores que mais do que zelar pelo nome de Deus, os irmãos secularizavam em demasia a comunidade. Os visitadores acusavam as irmandades de incontáveis vezes liquidarem as rendas necessárias para a manutenção das missas cotidianas. Até antes da chegada do Bispo, em 1745 , visitadores como o procurador do bispado do Rio de Janeiro. Frei João da Cruz, chegaram ao extremo de proibir as festas com grande espetáculo, considerando-as ostentação nociva à gravidade religiosa. Manifestações de censura e proibição não eram raras, como podemos ver na determinação abaixo:

[...] não façam mais festas da Irmandade com música, armação, sermões, nem senhor exposto, e somente poderão fazer e festejar à Senhora do Rosário com uma missa cantada, e outra a São Benedito, e com o rendimento da Irmandade satisfaçam os sufrágios e ofícios pelos irmãos defuntos, evitando as despesas supérfluas que não servem de utilidade para a Irmandade (apud Eugênio, p. 36).

Como mostra Patrícia Ferreira dos Santos (2006), a intervenção do Estado, através de bispos como Dom Frei Manuel da Cruz, $1^{\circ}$ Bispo de Mariana, buscava a correção de usos e costumes através de um processo contínuo de controle dos livros das irmandades, até mesmo chegando à dissolução das associações por falta de obediência aos "compromissos" ou posturas julgadas como indecentes para o trato da religião. O próprio bispo alertava em missiva ao rei Dom João V sobre as conseqüências da "irmandade secularizada" (apud Santos, p. 9). A disputa travada entre irmãos (em muitas delas considerável número era de funcionários régios) e poder eclesiástico chegou até mesmo à via armada, tendo interferência real favorável ao Bispo, como ele próprio relatou ao Papa (p. 8).

E essa era uma diferença essencial dos conflitos envolvendo músicos na primeira metade do século XVIII para o período posterior. A partir do reinado de 
Dom José I, a doutrina de controle através da Igreja mudou drasticamente e com ele, as características dos embates sobre a música. O primeiro fenômeno a ser destacado é que os contratos com os artistas e religiosos entraram no princípio de mercado. Os festeiros, entre eles os "partidos" de música, passaram a adquirir os serviços através de pregões públicos, nas celebrações organizadas pelo Senado da Câmara. Em síntese, a música se tornou um bem patrimonial do Estado e não mais regida pela relação estabelecida pela provisão do mestre-de-capela. Isso redimensionou a própria administração musical eclesiástica. Tanto o estanco da música como o licenciamento, de forma indireta, sofreram ferozes e sistemáticas resistências germinadas na esfera civil. Sua quebra, paulatina, se deu tanto pelo combate legalista como pela intensificação do pregão público para destinar direito sobre as funções musicais, como podemos ver a seguir.

Outra diferença a ser sublinhada é que os festejos públicos passaram a articular de forma mais intensa a idéia da união racional, e não mística, ao redor do monarca (Lopez, p. 43). A Igreja era chamada a participar, mas encontrava grandes resistências para estabelecer os padrões da mensagem, mesmo que simbólica. Nesse sentido, os instrumentos de controle passaram a ser a persuasão e não mais a inserção decidida de ferramentas de controle autoritário, como o estanco. Assim, as festas, sem perderem o elo com o religioso, passaram por uma transformação considerável, privilegiando as manifestações dos "divertimentos", como a ópera e os bailes.

Conscientes da importância do espetáculo do poder, muitos governadores no Brasil, entre eles, e muito especialmente, o governador de São Paulo, Luís Antônio Botelho de Souza Mourão, o Morgado de Mateus, fizeram questão de que os espetáculos públicos fossem realizados sempre com a maior pompa possível, submetendo a coesão social pelo fausto das cerimônias.

Em São Paulo o projeto cultural do governador ilumina os padrões da ideologia vigente, já que a autoridade considerava a fragilidade da elite local e a vocação paulista para o descumprimento do estatuto colonial, ajustado em grande parte pelas celebrações públicas, 
não só para cumprir com o seu afeto e com o muito que deve ao seu Senhor, mas também para imprimir nos corações desse povo a veneração e a obediência ao seu soberano e fazer adiantar o conhecimento do seu real nome que nessas remotas partes em muitos indivíduos era ainda ignorado (apud Nery, 2006, 56' 57").

Assim, suas festas primavam pela ostentação forjada na intersecção dos gostos populares, como os bailes e folguedos de forma geral, com as manifestações da elite, como a ópera e academias literárias. Para tanto, formou uma capela musical e uma companhia de ópera própria, atualizadas com o que era tocado na Corte lisboeta; promoveu academias lítero-musicais; ornou igrejas, dotando-as, em alguns casos, de pequenos órgãos; apresentou-se sempre diante de paradas militares com grande aparato musical, importando inúmeras vezes músicos "que se acharam mais especiais nas Terras da Capitania, e das vizinhas de Minas Gerais" (Nery, 2006); incentivou bailes populares, cavalhadas e farranchos; e representações teatrais de diversas espécies.

De tal forma era sua dedicação às festas, que uma frase da Relação das Festas Públicas para a Colocação da Imagem de Sant'Ana, na capela do antigo Colégio dos Jesuítas, resume sua disposição: “concluiu-se as festas com público 106 aplauso e universal aceitação de todo este povo [de São Paulo] que igualmente respeita na pessoa de Sua Excelentíssima, um general que sabe governá-lo, e diverti-lo" (IEB/USP, seção de manuscritos, coleção J. F. de Almeida Prado, n. 39).

No entanto, esta aparente regularidade e coesão das festas encobriam tensas relações na realização de seu projeto. Desde 1774, num processo já bastante conhecido da musicologia luso-brasileira (cf. Duprat, 1995, p. 57-58), o governador acima citado travou uma intensa disputa sobre o direito de prover os músicos que ocupariam a Sé paulista, revitalizando a querela da investidura vivida pelo arcebispo Dom Sebastião Monteiro da Vide, em meados de 1710. Esse intrincado jogo de forças com o $3^{\circ}$ Bispo de São Paulo, Dom Manuel da Ressurreição, tinha como fundamento uma profunda alteração do padrão de organização do espaço público. O Bispo não abria mão de nomear gente de sua confiança e assim promoveu não só a nomeação do mestre-de-capela da Sé, mas 
incentivou nas inúmeras freguesias a nomeação de músicos pelas mãos dos vigários locais. Diante da insistência do Bispo, Dom Luiz Antônio fez uma denúncia ao Conselho Ultramarino sobre o que considerava um abuso de autoridade: "Acresce além disto passar o Exc. Bispo provisões para mestre-decapela de todas as vilas e freguesias impondo thes a pensão de dez tostões na forma da provisão de que junta a copia." (AHU, Documentos referentes à Capitania de São Paulo, doc. 2666).

$\mathrm{Na}$ medida em que avançava o tempo no encontro das reformas pombalinas da segunda metade do século XVIII, a reação contra a antiga doutrina de controle do espaço público pela Igreja conseguia mais mobilizações. O bombardeamento político que sofria o campo de influência religiosa na sociedade deixava vulnerável a continuidade da prática, por exemplo, de estancar a música. Não havia qualquer pudor, então, de classificar esse costume das autoridades eclesiásticas, que "sem serem músicos, e às vezes cantando bem mal, tirando melhor partido do que ninguém das músicas" como um "abuso que podia introduzir a violência, e tolerar a paciência dos povos" (IAN/TT, Papéis do Brasil, cód. 15, §92).

Porém a nebulosidade da questão continuava vigente. Em 1755 segundo um anexo contido nos autos de um processo de 1774 (AHU, doc. 2666)

- D. José I teria concedido aos bispos o direito de prover os mestre-de-capela. Paradoxalmente, em 1761, o mesmo rei determinava através de uma provisão do Cardeal Patriarca de Lisboa, que "pessoa alguma da jurisdição eclesiástica se intrometa nas funções festivas no exercício da música sem ser professor dela ou irmão da [...] Confraria [de Santa Cecília]" (Lange, 1966, p. 50). ${ }^{5}$

Ao que parece, um longo período se passou para que a prática do estanco se diluísse, devido à força do costume e à resistência da Igreja. Ainda em

\footnotetext{
${ }^{5}$ A Irmandade de Santa Cecília dos Músicos de Lisboa (Lange, 1966, p. 45) surgiu em Portugal em 1603. Segundo Curt Lange (p. 45), desde o início patrocinou a regulamentação da atividade musical lisboeta. Contou sempre com a proteção dos nobres da casa de Bragança. Após o terremoto de 1755, seus membros elaboraram um compromisso que, na interpretação de Lange, constitui-se como um verdadeiro manifesto sindical. Expandiu suas atividades até o século XIX, quando foi substituída pelo Monte Pio Philarmônico (p. 47).
} 
1782, a coerção ao estanco desatou um processo que pôs os músicos da vila de Santos, associados ao mestre-de-capela da matriz, André de Moura, em franco conflito com as autoridades civis.

Diante da desobediência do mestre-de-capela, o Juiz de Fora de São Paulo orientou seu colega santista dizendo que era necessário que cessassem os conflitos "de jurisdição que os músicos das capelas da música, das freguesias desta capitania tem tido com os mais músicos a respeito da primazia que aqueles querem ter nas distas festas." (DOCUMENTOS INTERESSANTES, p. 184, v. 5). 0 juiz acreditava que era necessário que o povo tivesse presente a determinação de Dom João V, de 1709, que ditava aos eclesiásticos "só pertence determinar o que e como se deve cantar nas Igrejas, se ao profano, se ao Divino, e proibir cantos desonestos e menos descentes" (apud Duprat, 1999, p. 66).

De todas as formas, vemos que a desordem causada pelo mestre-decapela da matriz santista respondia a uma perda de integridade de seus privilégios. A antiga autoridade dos providos sobre o exercício da música aos poucos ia sendo, também, desamparada pela Igreja, não por motivos de vontade própria, mas pela fluência de uma sociedade menos amarrada à sua zona de influência na determinação do espaço lúdico e, por que não, à própria diversidade das festas, com seus bailes e óperas.

Assim, a conquista do espaço profissional foi se configurando, marcada não pela força impositiva da Igreja, mas pela adaptação do músico ao mercado de trabalho profano. Sem dúvida, continuou valendo a influência da Igreja e das irmandades; no entanto, o enfrentamento entre o sacro e o profano revelava as tensões desse ambiente, já bastante difuso.

Em 1807, um documento intitulado "Os músicos devem ir de baixo da cruz da matriz ou fazendo alas ou no meio da procissão como se costuma em todas as partes e o M. R. do Vigário os admoeste por isso", (Arquivo Nacional do Rio de Janeiro, Convento do Carmo de Santos, rolo 13.3.77) revela os muitos contornos da perda das tradições que iam lentamente se dissolvendo na consciência até mesmo daqueles que sempre viveram delas: 
Diz o padre Prior do Convento de Nossa Senhora do Monte do Carmo da vila e praça de Santos, que sendo a sua comunidade [convidada] para as Procissões Régias, que saem da Igreja Matriz daquela Vila, a faz desde certos anos ser nelas injuriosamente presididas com as mais religiões, incorporadas na sua comunidade pelo mestre-de-capela e sua música vestidos de secular, que em alas se portam diante da cruz da fábrica da matriz e porque esta ação seja totalmente oposta a toda cerimônia, bem entendida da Igreja, a qual determina, que em ações eclesiásticas ninguém deve pagar aos eclesiásticos por sua ordem, exceto por obséquio os magnatas dos lugares, sendo estas mesmas tão louváveis cerimônias patrocinadas por Sua Majestade nas procissões de Corpo de Deus, cuja circunstância atendível tem sido desprezada naquela vila pelo reverendo pároco, que com o frívolo pretexto deste abuso introduzido, não da as devidas providencias sobre este abominável absurdo, e pública injúria, requerido foi em [praça] foi a face de todo o povo pelos [...] Prelados daquele Convento seus predecessores [...] (Arquivo Nacional do Rio de Janeiro, Convento do Carmo de Santos, rolo 13.3.77).

O processo desencadeado a partir da segunda metade do século XVIII alterou consideravelmente o eixo dos conflitos. Até a própria configuração da festa remodelou-se. Na esfera social, uma das mudanças mais sensíveis diz respeito à relação com os ambientes: a casa passou a ser o centro da convivência, e não a rua, que passou a ser um "lugar de passagem e não de encontro" (Lanna, 1996, p. 105). A música "dos barbeiros”, por exemplo, era nas primeiras décadas do século XIX, no Rio de Janeiro, uma presença "quase tão essencial quanto o sermão" (Abreu, 1999, p. 54). Memorialistas indicavam que o repertório era constituído de vários ritmos de danças, como quadrilhas e fandangos.

No entanto, se a música profana não era mais combatida por provisões eclesiástica nem por censuras oficiais, ainda causava escândalos numa elite que tratava de se adequar aos novos padrões de convivência social, após a chegada da corte no Brasil. Assim, e apesar de continuarem sendo alvo das marcas da incivilidade, principalmente as que suscitavam gestos sensuais, como os lundus, a censura às práticas lúdicas se associava a um projeto de civilização, regido nos protocolos da ordem pública. Surgiu então a repressão policial sistematizada, considerando a festa local de desordem e potencialmente apta para rebeliões e motins, principalmente de negros. Identificadas como signos da balbúrdia, os eventos se tornaram inapropriados para as elites. Até mesmo o entrudo, antigo costume da colônia, foi substituído no decorrer do século XIX por uma forma 
mais organizada de celebrar: o carnaval. Ainda nos alvores dessa centúria, a Intendência Geral de Polícia passou a exigir autorizações para as realizações de procissões e festas (Abreu, p.189), principalmente aquelas que traziam o signo do sincretismo religioso, marcado pela presença da cultura negra. Em síntese, na transformação do sentido da festa, o novo tipo de conflito consubstanciava e sublinhava os padrões dos antigos preconceitos de casta, agora os reprimindo pela polícia.

Nesse espaço, o músico distante dos salões e teatros foi se cristalizando à margem da civilidade requerida pela elite, principalmente na corte do Rio de Janeiro. Ironicamente, os descendentes dos antigos mestres-de-capela, que no século XVIII tinham forte presença na articulação social, sofreram uma desvalorização sem precedentes: o mestre-de-capela transformou-se em mestrede-banda e seu universo tornou-se a rua e não os teatros; a música ligeira seu desígnio e não a que trazia o signo da civilização, como fora outrora.

Ana Lúcia Lanna (p. 130-131) observa que justamente essa tendência à elitização das festas foi a base para a criação de clubes e a marginalização de manifestações populares - como os batuques dos negros e suas danças, tradicionais integrantes das celebrações públicas coloniais. Nota ainda que, de modo geral, as festas perderam a espontaneidade de expressão e se transformaram em espetáculos, o que marcava a nova era de participação do povo (p. 142). Nesse mesmo processo, a categorização da música em estratos sociais sedimentou preconceitos que consolidou, no século XIX, um turbilhão de elementos que imprimia à festa e as formas de sociabilidade do século XVIII uma decadência irreversível, como afirma Martha Abreu:

[...] até o final do século [XIX], o número e a pompa das procissões diminuíram; as tradicionais festas perderam popularidade e a do Divino Espírito Santo, a maior delas, transformou-se em festa de paróquia. As irmandades, por sua vez sofreram sérias críticas e alterações no seu antigo papel (1999, p. 98).

Enfim, nos turbilhões das mudanças de sentido operadas pelas estruturas políticas, a música como elemento histórico-social viu-se, e sempre se vê, frente a 
um interminável jogo de novos contextos que determinam padrões estéticos, formas de uso determinadas pelas intersecções com zonas de interesse e poder. Porém, nesses entreatos das ideologias, as vidas se perdem sem direção, acusadas de serem o que são: vidas de artistas!

\section{Referências}

ABREU, Martha. O Império do Divino; Festas religiosas e cultura no Rio de Janeiro, 1830 1900. Rio de Janeiro: Nova Fronteira (Coleção Histórias do Brasil).

CALAfATE, Pedro. Metamorfoses da Palavra: Estudos sobre o pensamento português e brasileiro. Lisboa: Imprensa Nacional/Casa da Moeda, 1998 (Série: Temas Portugueses).

CAMARGO, Cônego Paulo Florêncio da Silveira. A Igreja na História de São Paulo. São Paulo: [s.n.], 1953. v. 4.

BUDASZ, Rogério. A música no tempo de Gregório de Mattos. Curitiba: DeArtes/UFPR, 2004.

DUPRAT, Régis. Música na Sé de São Paulo colonial. São Paulo: Paulus, 1995.

. O estanco da música no Brasil colonial. In: MARCONDES, Neide; BELLOTTO, Manoel (Org.). Labirinto e Nós; imagem ibérica em terras da América. São Paulo: Editora da Unesp: Imprensa Oficial do Estado, 1999. p. 53 - 74.

EUGÊNIO, Alisson. Tensões entre os Visitadores Eclesiásticos e as Irmandades Negras no Século XVIII Mineiro. Revista Brasileira de História. São Paulo, v. 22, n. 43, p. 3346, 2002.

FRANCO JR., Hilário. A Idade Média: o nascimento do Ocidente. São Paulo: Brasiliense, 1986.

LANNA, Ana Lúcia Duarte. Uma cidade na transição; Santos: 1870-1913. São Paulo: Hucitec, 1996.

NERY, Rui Vieira. A música na estratégia colonial lluminista: o morgado de Mateus em São Paulo (1765-1774). Conferência. São Paulo: Instituto de Estudos Avançados - Universidade de São Paulo, ago. 2006. Vídeo (duração: 1h 50min). Disponível em:

<http://www.iea.usp.br/iea/online/midiateca/videonerymorgado060828.html>. Acesso em: 17 nov. 2007.

LANGE, Francisco Curt. A organização musical durante o período colonial brasileiro. Coimbra: V Colóquio Internacional de Estudos Luso-Brasileiros, 1966. 
MACHADO NETO, Diósnio. Administrando a festa: Música e lluminismo no Brasil colonial. 2008. Tese (Doutorado em Musicologia) - Escola de Comunicação e Artes, ECA, Universidade de São Paulo, São Paulo, 2008.

MOTT, Luiz. Cotidiano e vivência religiosa: entre a capela e o calundu. In: SOUZA, Laura de Mello e (Org.). História da vida privada no Brasil: cotidiano e vida privada na América Portuguesa. São Paulo: Companhia das Letras, 1997. p.155-220.

PRIORE, Mary Lucy Murray. Festas e utopias no Brasil colonial. São Paulo: Brasiliense, 1994.

REIS, João José; SILVA, Eduardo. Negociação e conflitos: a resistência negra no Brasil escravista. São Paulo: Companhia das Letras, 1989.

SILVA, Luiz Geraldo. Da festa barroca à intolerância ilustrada. Irmandades católicas e religiosidade negra na América portuguesa (1750-1815). In: SALLES-REESE, Verónica (Org.). Repensando el passado, recuperando el futuro. Nuevos aportes interdisciplinarios para el estudio de la America colonial. Bogotá: Editorial Pontificia Universidad Javeriana, 2005. p. 270-287, v. 1.

SANTOS, Patrícia Ferreira dos. Igreja, Estado e o Direito de Padroado nas Minas Setecentistas através das Cartas Pastorais. Cadernos de História. Departamento de História da Universidade Federal de Ouro Preto, ano 1, v. 2, set. 2006.

SOUZA, Laura de Melo e. O sol e a sombra: política e administração na América portuguesa do século XVIII. São Paulo: Companhia das Letras, 2006.

TINHORÃO, José Ramos. A música popular no romance brasileiro. São Paulo: Ed. 34 , 2000.

\section{Abreviaturas e siglas de arquivos e coleções citadas}

$\begin{array}{ll}\text { ACMSP } & \text { Arquivo da Cúria Metropolitana de São Paulo } \\ \text { AHU } & \text { Arquivo Histórico Ultramarino (Lisboa - Portugal) } \\ \text { DAESP } & \text { Divisão de Arquivo do Estado de São Paulo } \\ \text { IAN/TT } & \text { Instituto do Arquivo Nacional/Torre do Tombo (Portugal) } \\ \text { IEB/USP } & \text { Instituto de Estudos Brasileiros da Universidade de São Paulo } \\ \text { IHGSP } & \text { Instituto Histórico e Geográfico de São Paulo } \\ \text { PGA } & \text { Processos gerais antigos do ACMSP }\end{array}$

Diósnio Machado Neto: diosnio@gmail.com

Artigo recebido e aprovado em 10 de agosto de 2008 